方デヘナカラウカ。

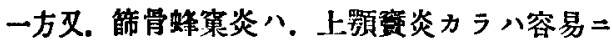
起り易イモノデアルカラ。它丈が一緒二侵サレ

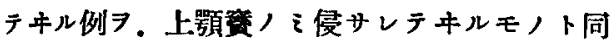
一意味ニ考へタトシテ．上ノ統計ア見テモ。10 $\%$ \% $\%$ トリ低然トシテ所謂齿性蓄膿症/大 部分八。豫メ變化ノアッタ粘膜=起ルト考へラ

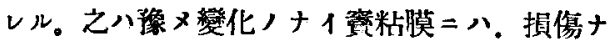
ドガ起ツテモ，又感染シタ鮽ナドガ落込ンデモ 高タ.「レントダン寫貪二八現レナイ程度，限 局性/變化习起スノミデアルト言フ前述/自分 /經驗二一致スル。

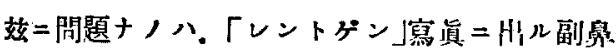
院/㓌影力゙。何八程度迄，粘膜八變化 7 意味 ルモノトナシ得ルカト云フ事，及ビ夫レカ粘膜 /變化トシテモ。如何ナル種類ノ變化デアルカ ト言フ事デアル。第 1 人閭題二就テハ。手術所
見卜比較シテ/自分，經驗カラ推シテ．大部分 八粘膜，變化二歸シ得ルト言スコトヨ信ズル。 第 2 ，問題二就テ八，先ヅ先灭的=粘膜が厚 1 事がアリ得儿事。次＝非染性，「アレルギー」 性反雇ノアリ得ペキ事タ侾へネバナラナイ。而 シフ此「アレルギー」性變化八，單ナル浆液性 ，炎症卜區別スル事が困繁デアリ，之ガ傮染性 炎症，下地卜モナル事ヨ考へラレル。丁度中耳 八嶈液性炎症力゙。其傳染性炎定，下地トナル樣 。自分八竝デ。管テ經驗シタ，胎兒，鼻=

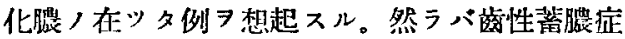
ノ大部分二於テ下地トシテ喼メ存スベキ病變ハ

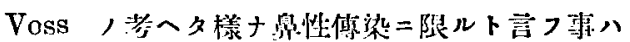
帅來ナイデアラウ。及上述ノ少數例ノ經驗=依

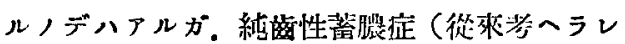
タ栐ナ）モアリ得ルト惹へラレル。之等ノ㫮: 於テ自分八Voss卜意見ヨ異ニスルノデアル。

\title{
「州行發音不能症, 治療二於ヶル經驗
}

Erfahrungen bei der Behandlung von Sigmatismen.

von Dr. Desider Weiss.

[Aus practica oto-rhino-laryngologica Vol. 1, S. 248.]

「甘」行發豆不能者ノ大部分八治癒シ得ルモ ノデアルカラ. 其治療法ト言ブラニ八. 今迄 餘り治蹽ノ效果ノナカッタ例二適シ. 又今迄, 方法ヨリ早ク．容易二效果ガ上ルト言フノデナ ケレパナラナ1。茲ニ報告スルノハウィーン大 學/言語矯正部二於テ贺ク良好卜認メラレタ䊷 驗デアル。然シえガ唯一, 良法ダト言フノデハ + 。

S系鼻 $(\mathrm{S}, \mathrm{Z}, \mathrm{Sch})$ 八各國語二化リ，又方 言二訨り種々二㡎吾サレル。故二自分八今. 獨
逸話ノウィーンニ於ケル經驗二限ツテ㻅ジル

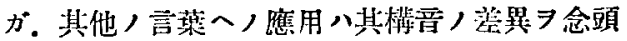
ニ䁂イテナサレタイ。

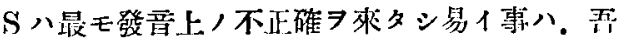
吾ノ所デ見タ該脂 (Stammelnde) 及ハ夫レト 結命シタ管語障碍者總數 500 例ノウチ. 446 例 こS系が不正確デアルコトヨ見テモ物ル。之ハ $\mathrm{S}$ 發スルロノ形が最モ融通性ニ之シク.少シ ノズレモ直グ耳立ッテ聞エル篇メトサレテキ ル。Barzinski ハ之

\section{2-167}


ト言フ表現法フ用ヒテキルガ. $\mathrm{S}=$ 關シテハ生

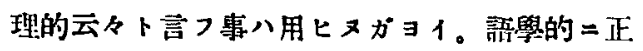
確か否カ八生理的カ否カ二依テ定マルノデナ ク、習慣が決メルバアル，A音等八其發音二 際シ。附蛝管二於ケル機能過多が見ラレルコト アリ。夫レ八非生理的卜言フ表現习用ヒルコト ガ出來ルガ.夫レンシテモ此場合。熟學的二八 正確タョ失ハナイノデァル。

齿列八不正が「行發豆不能掟，原因トナル

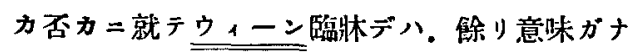
イト言フ結猃二洼シタ。唯次ノ事ハ該へル， 八正中線デ作ラレルカラ. 正中線上/端列不正 八之が原因トナリ得ルト。

Barzinski 八之力゙列不正トヨク一緒二來ル事 宽习證明シテ. Racbitis $尹$ 兩者，共通原因卜考

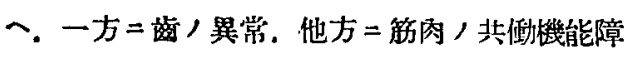
碍ヨ柬七ルモノトシテキル。上述セル樣ナ $\mathrm{S}=$ 就テノ微妙ナ共働作用八正中線二承儿種々।珙 常二依ツテ可ナリ損ハレル。又一方. 䇟肉, 弱 イ事. 障碍サレテキル事モ原因トナル。敦レン 七ヨ. $\mathrm{S}$ 咅ノ障碍八站列ヨリモ. 洪偅作用ガ平 滑二行クカ否カ二關スルノデアル。头レガ證幏

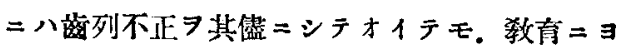
り矨正が出來儿。又 Gumpartz, Román, Kopp 等が「サ」行發湆不能省，多數二於テ。其他， 浯こモ不正ガアル事习述へテキルノモ，以上，

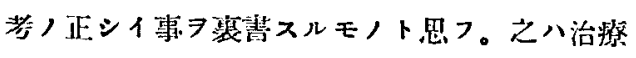
ノ上二注意スベキ事デアル。

吾々ノ所デナス治療方針八次ギ，榡二總括デキ ル。郎チ既存人誤ツタ鬲习正スト言フノデナ ク、全然新シイ出發點カラ出ナホス。發落ト言 フノデナク．單純ナ息习吹キ出スト言フ䨒カラ

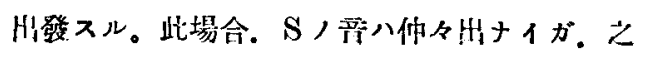

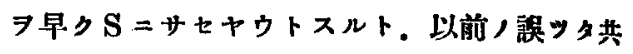
儌作用 ヨ使ツテシャツテ. 却ツテ效果がナ1。 種タト息习吹カセテ． $\mathrm{S} カ ゙$ 出タ時. 何回デモ正 確ニ出ルヤウニサセ．ソコデ之ヨ以前ノ不正士

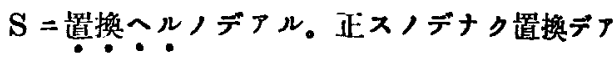
ル。繑正用器具ハナルベク用ヒメがョ1，唯特 二治り=クイ時ニ八.「世」行發吾不能症板/樣

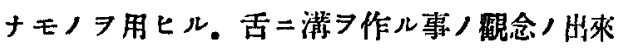

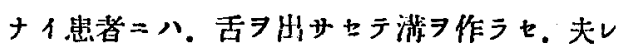
习成列ノ中=引込メル方法ヨトル。

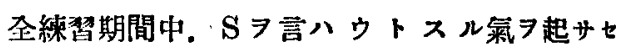
ズ. 唯息习舌卜觜ノ間カラ吹キ出ス事ヨ念頭= オカシメル。夫レフ結局 $\mathrm{S}$ ＼cjkstart發音サセル篇メト 患诸自身ニ八分ッテキテモ。息八吹キ方が ナル迄八.夫ヨSト呼バヌ事が大切デフル。 此方法八全り心理的方法デナリ．無理=齿列7 閉ヂサセテ镉正ス几等ノ機峨的方法习避クデ

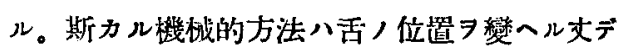
㭗章ノ矯正ニハナラナイ。

Fröschels 八練習八短時間シ、。繰返シ行へト 教へル。一度二長ク䋶ヶルト注意ガ散リ，機誠 的ニナル。之八禁物デアリ。特二初期二於テ甘 ウデアル。及一度出タ正シイ羙ノ甘シ方記憶 サセル䉥メニ八．注意が充分ナル事が必要デア ル。夫レニ八正シ偣が出タナランコデ練相习 中止之．30分以内二又行八セル。然ラズシテ少 ホ繶ケルト，龍ガ正シク出七ナクナツテシマ

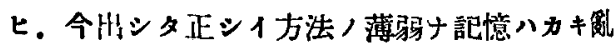
サレテシマフ。初メ八正シイ害八察口偶然二出 ルノデアルガ. 此偶然二關スル記憶八. 此释二 シテ强メラレテ行ク。 次二其細カ1方法兯述ベル。 Frọichels，下音法ト彷付クルモノデアル。患 


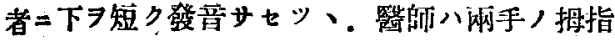
示指习患者ノ上下脣ノ間ニ入レテそラ開ク。次 二患者自身/指デえヌサセル。次二八指习用七

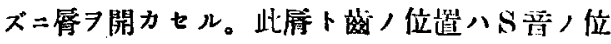

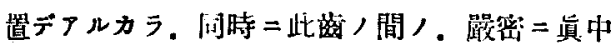
カラ息习吹キ出サ七ル。此意八、ナルベク鋧ク 細1氣流トナル樣二努メサス。前二釣ルシタ紙 片デモ吹キッヶル㧼ナ氣持デアル。之ニハ舌 加減スルノデフル。トモスルト舌 7 蓄二强クッ

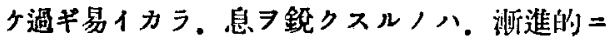
弱1方カラ强メテ行カセル。

$\mathrm{T}$ カラ $\mathrm{S}=$ 入ル方法七從來行ハレタガ。上述， 方法ニ、Tノ利用 7 結合サヒルトヨイ。郎チ $\mathrm{T}$, $\mathrm{TE}, \mathrm{TA}$ 等7基音, 後ニソケ加へル。此際 $\mathrm{S}$ ラ Tへノ移リ行キ八.ナダラカナル樣二努メ ル。難聽者二八上述/方法艾デハ完全ナ $\mathrm{S}$ ，概 念が得ラレナイカラ、Tカラ出發スル。又重第 ナ器筫的障碍（口篮破裂，如キ）がアレバ ST ヨ極メテ强ク發肯サセル。

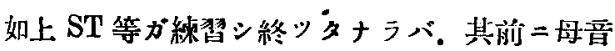
タッケテ ASTA, ESTE等ア發セシメル。此時 期ニハ多少銳クナリ過ギルノハョイガ. 舌ヨ餘 リ蒰ニオシックルノ八宜シクナイカラ注意ス 几。茲デ初メテ夫レガ正シ1 S / 音デアル事 数ヘル。次 $=\mathrm{S}$ 7離シテ發畐サセル。

之が出來タナラ、 $\mathrm{S}$ 前=母音 7 ッル文，

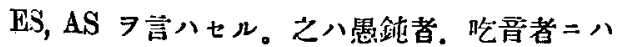
仲々困難デアルカラ.ハジメ離シテ發自サセ。 次第二間 7 緶メサセル。

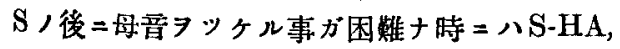
S-HE $尹$ 言ハシメル。然シ無響音 (stimmloser Laut) カラ有響急 (stimmlafter Laut) =移

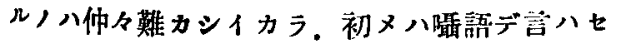

ルノデアル。斯クシテ头レガ留通二出ル棈ニナ ッタ洔. S-HA, S-HA, S-HA フ絬ケテ是ク云 八ス。

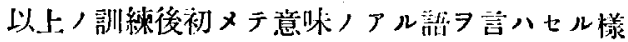
ニスル。器用ナ患者デハ. Fカラ $\mathrm{FS}$ ヨ找イテ $\mathrm{S}$ 二入ル事がアルガ．之八稿デアル。然ル =一方 刃. えモ鼠ダ稀デハアルガ，非常二浿症デ「サ」 行發舀不能症板 $\ni$ 要スルモノがフル。之八最モ

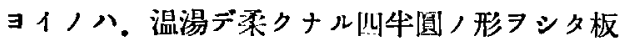

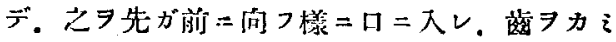

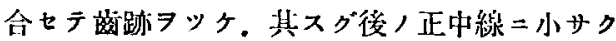

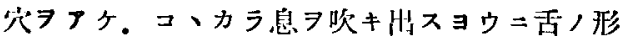
フエ头サセルノデアル。

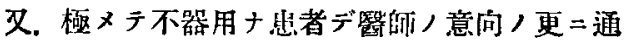
ジナイ時ニ八，所謂上部 $S$ (oberes $S$ ) ナルモ ノタ出サシメル。夫レハ舌端ヨ木筐デ上=押シ

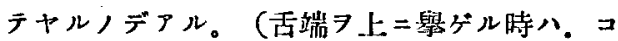
コデ氣流が細クナリ．舌端 7 前崡二近クスル時 八舌背部デ氣流 7 細メル事トナルノデ、前著 7 舌端性 $S$ (dorsales $S$ ). 後脂 7 舌背性 $S(2-$ picales S) ト呼ブ人ガアル。

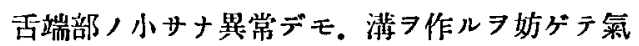
流习正シク出ス事が出來ズ二，押シッケラレタ 㧼ナ音トナルコトがアル。之八特二美シイ $\mathrm{S}$ 音 フ要スル俳優等ニ八困ル事デアル。

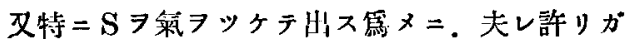
强クナルコトガアル。此時八忽者二出棵ル才䡰 ヨ小サクシ. 5-6步離レタナラ聞エナイ位二話 ヨサセル。スルト患者自身二モ其缺默が分ッテ

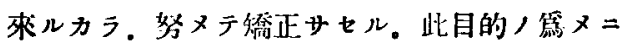
Böck $ハ$ Fröschels , Atemessen 法习用ヒタ。 印チ患者ヨシテ恰モ心地ョク食事ヨスル樣ナ本 稱ナ氮持デ會話二對セシメルト言フ意阙デア 
ル。又基默ナ患者ニハ却ッラ跣語デ强ク喍ラを ル方法テトル。㵵語デ人二解ラセル第メ二八患 者八自然二銳り發音スル椂ニナルカラデアル。 又習得シタ正シイ $\mathrm{S}$ 音/利用ヨ忘レテキルコト

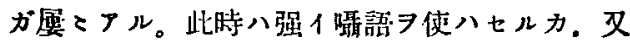
八讀物ノ $\mathrm{S}$ 豆ノ下ニ「アンダーライン」ヨヒク

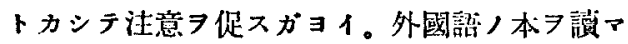
セルノモ各音二注意が向フノデョイ。

Fröschels 八最近頭フ後へ傾ケルト。多クハS 昔/口萻性化 (Palatalisierung) ガ起り。前へ 倾ケルト落間性化 (Interdentalität) ガ起ルト

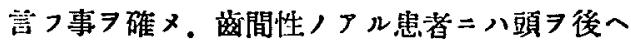

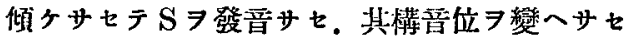

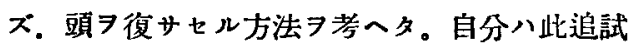

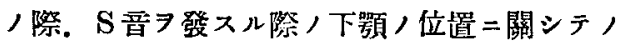
知見 $\exists$ 得夕。最初八 $\mathrm{S}$ 音八時八下顎八前二出ル ト考へラレテ居タ。Fröschels ハそニ對シテ.

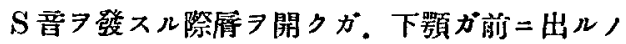
八愿ヨ開ク際=下顎が出ル人=限ルノデフッテ 人二依ッテハ愿ヨ開ク際下顎ハ必ズシモ出ナイ ノデアリ．其人デハ $\mathrm{S}$ 音尹發スル際モ，下顎ハ 出ナイト言つ事デアル。そニハ Meder, Reichbach, Gutzmann 等/反對がアッタガ. 1933 年 Nadoleczny 等が Fröschels / 䒯习正當ヅ ケタ。

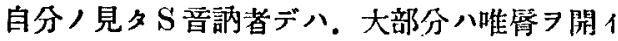

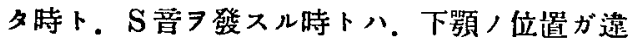
ッタノデアル。え=唯脣ヨ開イタ位渞デ セシメルト，正シィ乃至八ヨリ正確ナ $\mathrm{S}$ 音ガ出 タ。之等カラ考へテ自分八，患者が $\mathrm{S}$ 音习發ス

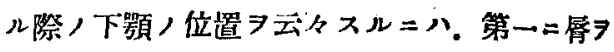
關カ七テ見ホバナラナイト䓂つ事・䊈へタイ。 $\mathrm{S}$ ガ出來レバZ 關題デナ1。Sch = 就テ少シ ク逝べレバ. 之八蒸氣機關，至カラ始メルノガ ヨ1。Fröschels 八L音/特. 舌 7 少シ上=舉 ダラセルト云フ。又既二習得シタ $\mathrm{S}$ 吾ヨり濑次

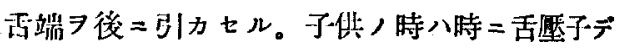
そョ押シテヤルトヨイ。此時嘫子ニハ入レル 染サノ目盛ヨックテォクノデアル。自分八 Sch ニ八脣が前二出ルト考へルガ. 夫レニシテモ豨

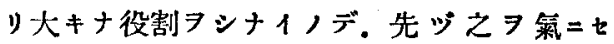
ズ. 脣习引イテ舌ヨ正シ. 後デ脣ヨ出スコトに スル。然シ實際會話デ八，局／位置ノ絶エザル

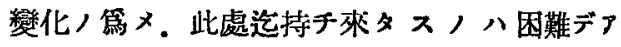
u。

Sト Sch トヨ同時二矯正シテハナラナ1。同

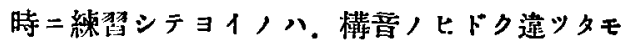
ノニ就テノミデアル。

或種/「年行發昔不能症」デ八有響性/ $\mathrm{S}$ 晋が ナイトツ. Fröschels”，確定シタ所デアルガ. 正シ1哭響性/ $\mathrm{S}$ カラ。有響性 7 習得スルハ サシラ困難ナ事デハナイ。

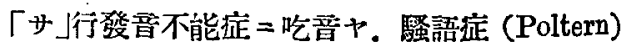
ガ結合シテンル場合八如何。第一ノ吃音八完全 ニ治療シテオイテカラ， $\mathrm{S}$ 音ノ矯正二移ルベキ デアル。吃昔が少シデモ殘ッテキルト．S晋稫 正二注意スル篇メ。吃亘ガ惡化スル。騷語症治

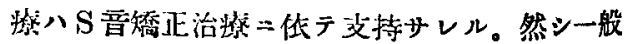

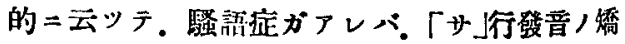
正八困難/度9增ス。 